\title{
PENERAPAN ART THERAPY DALAM MENGATASI FOBIA KUCING PADA INDIVIDU DEWASA
}

\author{
Arief $^{1}$, Monty P. Satiadarma ${ }^{2}$, dan Denrich Suryadi ${ }^{3}$ \\ ${ }^{1}$ Fakultas Psikologi, Universitas Tarumanagara Jakarta \\ Email: Arief.s0492@gmail.com \\ ${ }^{2}$ Fakultas Psikologi, Universitas Tarumanagara Jakarta \\ Email: monty_satiadarma@yahoo.com \\ ${ }^{3}$ Fakultas Psikologi, Universitas Tarumanagara Jakarta \\ Email: angiedenrich@yahoo.com
}

\begin{abstract}
ABSTRAK
Fobia kucing merupakan specific phobia yang ditandai dengan kecemasan berlebihan saat dihadapkan dengan kucing. Umumnya, fobia diatasi dengan intervensi yang berpendekatan behavioristik dan kognitif. Namun, art therapy merupakan pendekatan lain yang juga dapat digunakan untuk mengatasi fobia. Art therapy bermanfaat membantu individu menghadapi tekanan melalui media seni. Individu merasa aman dengan mengekspresikan pemikiran dan perasaan melalui media seni. Dengan demikian, penelitian ini bertujuan untuk mengetahui seperti apakah penerapan art therapy dalam mengatasi fobia kucing pada individu dewasa. Desain dalam penelitian ini adalah kuasi-eksperimen. Pemeriksaan terkait pengalaman-pengalaman tiap partisipan didapatkan dari wawancara. Setelah itu, art therapy dilakukan lima sampai enam sesi untuk mengatasi fobia kucing. Terdapat tiga partisipan yang terlibat dalam penelitian ini. Kondisi fobia ketiga partisipan sesuai dengan kriteria DSM-IV-TR. Salah satu partisipan mengundurkan diri setelah pemeriksaan, karena kediamannya sangat jauh dan jadwal intervensi dapat berpengaruh pada jam kerjanya. Kedua partisipan lainnya dihadapkan dengan kucing di awal, tengah, dan akhir sesi untuk mengetahui penurunan tingkat fobia. Evaluasi dilakukan dengan menggunakan pulse oximeter, kuesioner Severity Measure for Specific Phobia - Adult, dan Subjective Unit of Discomfort Scale (SUDS). Hasil intervensi menunjukkan partisipan pertama (UK) mengalami penurunan tingkat fobia dari kategori severe hingga mild. Setelah intervensi, UK mampu berjalan di dekat kucing. Sementara itu, partisipan kedua (CF) mengalami penurunan tingkat fobia dari kategori severe hingga moderate. Setelah diberi intervensi, CF sudah mampu mengusir kucing dengan menggunakan sapu dan lebih tenang. Hasil penurunan tingkat fobia antar kedua partisipan tidak signifikan, karena jumlah partisipan yang kurang mencukupi dan kurangnya sikap kooperatif dari salah satu partisipan.
\end{abstract}

Kata kunci: Art therapy, Fobia Kucing, dan Individu Dewasa

\section{PENDAHULUAN}

\section{Latar Belakang}

Di Indonesia, kucing liar ditemukan di permukiman, perkampungan nelayan, kawasan bisnis, dan tempat pelelangan ikan. Jumlah populasi kucing di Jakarta mencapai 47.000 ekor (Rimawan, 2014). Terjadinya ledakan populasi kucing juga terjadi di daerah Jakarta dan sekitarnya. Umumnya, kucing liar ditemukan di sekitar kedai makanan tepi jalan (Anastasia, 2016). Wilayah tersebut juga merupakan tempat yang seringkali dikunjungi individu dewasa awal (berusia 20 tahun ke atas) yang menghabiskan waktu bersama teman-temannya (Harrison \& Morgan, 2005).

Besarnya populasi kucing tidak sebanding dengan banyaknya jumlah penampungan hewan liar, khususnya kucing (Sinaga, 2014). Selain itu, masyarakat khawatir kucing akan mencakarnya atau mencakar benda-benda di sekitarnya, membuat terkejut, senang mencuri makanan, membuang kotoran di berbagai tempat, dan mengotori tempat dengan bulu-bulunya (Wima, 2015). Hal-hal ini meresahkan seseorang yang mengalami fobia terhadap kucing.

Berdasarkan Diagnostic and Statistical Manual of Mental Disorders American Psychiatric Association, 2000), specific phobia memiliki tujuh kriteria. Kriteria A, adanya perasaan takut 
berlebihan terhadap obyek atau situasi spesifik. Kriteria B, individu merasa cemas jika dihadapkan pada situasi yang ditakuti. Kriteria C, individu menyadari perasaan takutnya berlebihan. Kriteria D, individu cenderung menghindari situasi yang menakutkan atau bertahan dengan perasaan takut yang intensif. Kriteria E, reaksi-reaksi fobia secara signifikan mengganggu rutinitas, pekerjaan atau pendidikan, aktivitas sosial, atau menimbulkan distres. Kriteria F, individu yang berusia kurang dari 18 tahun mengalami reaksi-reaksi fobia dalam durasi minimal 6 bulan. Kriteria G, diagnosis specific phobia tidak dapat diberikan apabila individu memenuhi kriteria Obsessive-Compulsive Disorder, Posttraumatic Stress Disorder, Separation Anxiety Disorder, Social Phobia, Panic Disorder With Agoraphobia, or Agoraphobia Without History of Panic Disorder.

Salah satu bentuk intervensi yang digunakan untuk menangani fobia adalah exposure therapy. Sue, Sue, dan Sue (2010) mengungkapkan dalam exposure therapy klien akan dihadapkan pada situasi yang ditakutinya secara bertahap, baik dalam imajinasi maupun kenyataan. Systematic desensitization juga dapat diterapkan dalam menangani kasus fobia. Systematic desensitization dilakukan dengan membayangkan situasi yang menakutkan bagi individu secara bertahap dalam kondisi tenang (McGlynn \& Cornell, 1985).

Kraft dan Kraft (2010) melakukan penelitian mengenai penerapan in vivo dan in vitro desensitization untuk menangani fobia tikus (mouse phobia). Partispan dalam penelitian ini adalah seorang wanita (inisial: C) yang berusia 45 tahun. Proses desensitization dalam penelitian ini dimediasi dengan hipnosis. Selama menjalani desensitization dalam sesi pertama, $\mathrm{C}$ berhasil membayangkan duduk di sebelah tikus mainan dan menyentuhnya. Namun, ia mengalami kesulitan ketika membayangkan ekor tikus pada tikus mainan, sehingga ia tidak dapat menyentuhnya dalam imajinasi. Hal ini terjadi karena bentuk tikus mainan semakin menyerupai tikus asli. Setelah dicoba sebanyak dua kali, $\mathrm{C}$ akhirnya dapat duduk di dekat tikus mainan dalam imajinasi. Semakin lama, karakteristik tikus dalam imajinasinya dirancang semakin menyerupai tikus nyata. Akhirnya, $\mathrm{C}$ pun diminta memegang seekor tikus dengan kedua tangannya. Pada sesi akhir ini, perasaan takut $\mathrm{C}$ sudah berkurang dan tidak khawatir mengenai konsekuensi yang diakibatkan tikus.

Diana dan Wirawan (2010) menerapkan cognitive behavior therapy untuk mengatasi fobia kecoak dalam penelitiannya. Partisipan-partisipan yang dilibatkan dalam penelitian memenuhi karakteristik fobia kecoak berdasarkan DSM-IV-TR. Dalam proses intervensi, tiap partisipan diberi psikoedukasi mengenai vicious cycle (pengetahuan rantai masalah kecemasan dan upaya mengatasinya), relaksasi, dan teknik "taking a step back (berfokus pada masa kini)." Hasil intervensi ini menunjukkan berkurangnya simtom-simtom kecemasan secara signifikan.

Uttley, Stevenson, Scope, Rawdlin, dan Sutton (2015) melakukan penelitian mengenai pengaruh group art therapy dalam memulihkan kondisi individu-individu yang mengalami gangguan psikologis. Peserta-peserta dalam penelitian ini adalah individu yang mengalami gangguan psikologis non-psikotik, misalnya depresi, kecemasan, dan fobia. Dalam penelitian ini, art therapy dapat menurunkan intensitas gangguan pada tiap peserta secara signifikan.

Art therapy merupakan intervensi yang dilakukan melalui media seni untuk mengatasi keluhan klien (Edwards, 2004). Media yang digunakan dalam terapi dapat berpengaruh pada kondisi klien (Rappaport, 2009). Art therapy juga merupakan intervensi yang dapat digunakan untuk membuat individu merasa aman dan tidak mengalami keraguan dalam mengekspresikan hal-hal 
yang dialami melalui media seni (Hogan \& Coulter, 2014). Situasi dalam art therapy memunculkan perasaan aman, sehingga klien bebas bereskpresi dan mengungkapkan perasaan dan pemikirannya (Hogan \& Coulter, 2014). Dalam art therapy, relaksasi dapat dilakukan selama sesi intervensi. Relaksasi pada otot-otot tubuh merupakan teknik yang umum digunakan dalam art therapy (Wadeson, 1980). Dilakukannya relaksasi akan mengurangi ketegangan pada otot yang disebabkan perasaan dan pemikiran klien. Setelah relaksasi, klien merasa tenang dan dapat menjalani intervensi secara maksimal.

Salah satu pendekatan art therapy disebut focusing-oriented art therapy. Focusing-oriented art therapy merupakan pendekatan yang mengintegrasikan pendekatan focusing psychotherapy dari Gendlin dengan art therapy (Rappaport, 2009). Dalam prosesnya, klien diminta berfokus pada sensasi fisik dan perasaannya selama membuat karya seni. Focusing-oriented art therapy meliputi lima tahap. Tahap pertama (establishing safety), terapis menerima masalah klien yang diekspresikan dalam karya seni (Rappaport, 2009). Tahap kedua (reflection: empathic understanding), terapis memahami bahasa verbal, nonverbal, dan artistik, sekaligus merefleksikannya kembali kepada klien. Tahap ketiga (integrating art therapy into focusing), klien mengidentifikasi perasaan melalui sensasi fisik yang dirasakan. Tahap keempat (the felt shift: art and body), terjadi perubahan sensasi fisik terkait masalah yang dikeluhkan. Tahap kelima (integrating focusing into art therapy), klien sudah mampu mengatasi masalah.

Besarnya populasi kucing di Indonesia mengganggu individu dewasa yang mengalami fobia kucing. Secara umum, intervensi yang diterapkan dalam mengatasi fobia berdasarkan pendekatan behavioristik (exposure therapy dan systematic desensitization) dan kognitif (cognitive behavior therapy). Padahal, art therapy juga dapat dijadikan sebagai pilihan intervensi untuk kasus fobia, seperti penelitian yang dilakukan oleh Uttley et al. (2015). Jika dibandingkan dengan jenis intervensi lain, art therapy memungkinkan klien mengekspresikan pemikiran dan perasaannya secara bebas melalui media seni. Klien pun merasa aman untuk menghadapi tekanan yang diproyeksikan dalam media seni, sehingga dapat mengatasi masalah yang ada dalam kehidupannya. Penelitian yang mengkaji penerapan art therapy dalam mengatasi fobia hewan pun masih belum cukup banyak, khususnya fobia kucing. Dengan demikian, penulis tertarik untuk mengkaji lebih lanjut mengenai penerapan art therapy dalam mengatasi fobia kucing pada individu dewasa.

\section{Rumusan Masalah}

Rumusan masalah dalam penelitian ini adalah, "Seperti apa penerapan art therapy dalam mengatasi fobia kucing pada individu dewasa?"

\section{METODE PENELITIAN \\ Partisipan}

Awalnya, penelitian ini melibatkan tiga individu yang mengalami fobia kucing. Namun, art therapy diterapkan kepada dua partisipan, karena seorang partisipan mengundurkan diri setelah pemeriksaan. Agar kondisi fobia dapat diketahui, hal-hal yang dialami para partisipan dicocokkan dengan kriteria DSM-IV TR, seperti: (a) merasa takut secara berlebihan terhadap sesuatu; (b) merasa cemas terhadap sesuatu, terkadang disertai reaksi panik; (c) menyadari perasaan takutnya itu irasional atau berlebihan; (d) menghindar atau bertahan dengan hal yang ditakuti dengan perasaan tegang; dan (e) rasa takut mengganggu rutinitas, fungsi pekerjaan, fungsi sosial, atau menimbulkan distres (APA, 2000). Baik jenis kelamin, etnis, agama, dan status sosial-ekonomi tidak dibatasi dalam penelitian ini. 


\section{Persiapan dan prosedur penelitian}

Sebelum pengambilan data dilakukan, penulis menyebarkan informasi berupa kriteria partisipan dalam media-media sosial dan aplikasi-aplikasi chatting untuk menemukan partisipan penelitian. Dari proses rekrutmen partisipan, terdapat tiga orang partisipan yang memenuhi kriteria dan bersedia untuk berpartisipasi. Salah satu partisipan mengundurkan diri sebelum diberi intervensi, karena kediamannya jauh dan jadwal intervensi dapat memengaruhi jam kerjanya.

Selain merekrut partisipan, kuesioner Severity Measure of Specific Phobia-Adult diterjemahkan ke dalam Bahasa Indonesia. Oleh karena itu, alat ukur yang sudah diterjemahkan diuji ke 16 orang partisipan. Berdasarkan hasil analisis data, butir kesepuluh dari alat ukur tidak cukup reliabel. Berdasarkan expert judgment dari dua orang psikolog klinis (Dr. Monty P. Satiadarma, MS/AT, MCP/MFCC, DCH, Psikolog dan Denrich Suryadi, M.Psi, Psikolog), butir tersebut tetap digunakan dengan pertimbangan jumlah partisipan uji coba yang masih sedikit belum dapat menggambarkan secara tepat. Selain alat ukur ini, SUDS dan pulse oximeter juga digunakan untuk mengukur intensitas fobia. SUDS digunakan untuk mengetahui persepsi partisipan mengenai tingkat kecemasan yang dirasakan saat dihadapkan dengan kucing. Melalui angka yang tertera pada pulse oximeter saat partisipan merasa cemas, rata-rata detak jantung per menit dapat diketahui secara otomatis.

Sebelum pemeriksaan, partisipan diminta mengisi lembar biodata dan informed consent. Wawancara dengan partisipan dilakukan untuk memahami riwayat terjadinya simtom kecemasan dan fobia terhadap kucing. Setelah itu, art therapy diterapkan kepada para partisipan. Pendekatan yang digunakan dalam intervensi adalah focusing-oriented art therapy dari Rappaport. Setelah intervensi selesai, partisipan kembali dihadapkan dengan kucing dan detak jantungnya kembali diukur dengan menggunakan pulse oximeter. Selain itu alat ukur Severity Measure for Specific Phobia - Adult dan SUDS juga akan digunakan.

\section{Desain penelitian}

Penelitian ini dilakukan dengan desain kuasi-eksperimen. Dengan demikian, pengalamanpengalaman spesifik tiap partisipan akan dieksplorasi hingga mengalami fobia. Setelah itu, art therapy dilakukan untuk mengurangi kecemasan yang dialami saat fobia. Pengukuran tingkat fobia dilakukan di awal, tengah, dan akhir sesi.

\section{Setting lokasi}

Penelitian dilakukan di ruang konseling Fakultas Psikologi Universitas Tarumanagara. Ketika partisipan akan dihadapkan dengan kucing dalam proses evaluasi, sesi akan dilakukan di ruangan terbuka, misalnya di tepi jalan, dekat perumahan, atau dekat universitas.

\section{Perlengkapan penelitian}

Selama melakukan penelitian, penulis memerlukan lembar biodata, lembar informed consent, foto kucing, alat-alat lukis (kertas gambar A3, penghapus, tisu, dan pensil warna), kain rasfur, dacron, mata dan hidung buatan, jarum jahit, benang, kuesioner, serta pulse oximeter. Sebelum penelitian dilakukan, setiap partisipan akan diberikan lembar biodata dan informed consent.

Foto kucing, kertas gambar, pensil warna, penghapus, dan tissue akan digunakan di sesi pertama intervensi. Dalam tahap-tahap berikutnya, kain rasfur, dacron, mata buatan, hidung buatan, 
jarum jahit, dan benang akan digunakan. Kuesioner yang diberikan dalam penelitian adalah Severity Measure for Specific Phobia - Adult yang disusun oleh Lebeau, Glenn, Hanover, Beesdo-Baum, Wittchen, \& Craske (2012), dan SUDS. Pulse oximeter digunakan di awal, tengah, dan di akhir intervensi untuk mengetahui apakah kecemasan partisipan berkurang setelah intervensi.

\section{Pengukuran}

Sebelum intervensi, partisipan dihadapkan dengan seekor kucing di tempat-tempat umum seperti di tepi jalan, daerah perumahan, atau daerah universitas. Selama partisipan dihadapkan dengan kucing, observasi terhadap perilaku partisipan dan pengukuran jumlah rata-rata detak jantung dilakukan. Wawancara mengenai reaksi-reaksi yang dirasakan partisipan dilakukan setelah kondisi perasaan partisipan sudah lebih stabil. Kuesioner Severity Measure for Specific Phobia dan SUDS juga disajikan kepada partisipan untuk mengetahui tingkat fobia yang dialami.

\section{HASIL DAN PEMBAHASAN}

\section{Gambaran partisipan}

Secara umum, ketiga partisipan merasakan kecemasan dalam jarak 3-4 meter dari kucing. Kecemasan dialami ketiga partisipan setiap kali berhadapan dengan kucing. Kecemasan juga dirasakan para partisipan secara fisik, misalnya merasa detak jantung semakin cepat, bulu kuduk berdiri, dan kehilangan napsu makan. Dalam kondisi cemas pun partisipan berteriak atau melompat ke meja. Ada pula partisipan yang meminta bantuan orang lain untuk mengusir kucing. 
Tabel 1. Gambaran Fobia Partisipan

\begin{tabular}{|c|c|c|c|}
\hline No. & Partisipan & $\begin{array}{l}\text { Memenuhi } \\
\text { Kriteria Fobia }\end{array}$ & Simtom \\
\hline 1 & UK & $\sqrt{ }$ & $\begin{array}{l}\text { Merasa jantung berdebar dengan cepat, } \\
\text { berkeringat dingin, kehilangan napsu makan, } \\
\text { berteriak atau melompat ke meja saat ada } \\
\text { kucing, dan beranggapan rasa cemas terhadap } \\
\text { kucing berlebihan. UK juga merasa cemas saat } \\
\text { berhadapan dengan bulu-bulu yang serupa } \\
\text { dengan bulu dan foto kucing. Kecemasan } \\
\text { muncul saat melihat kucing dalam jarak } 3 \text { meter. }\end{array}$ \\
\hline 2 & $\mathrm{CF}$ & $\sqrt{ }$ & $\begin{array}{l}\text { Merasa cemas setiap kali melihat kucing dalam } \\
\text { jarak } 4 \text { meter. Perasaan cemas juga muncul saat } \\
\text { melihat boneka kucing yang menyerupai aslinya } \\
\text { dan foto kucing. CF merasa detak jantungnya } \\
\text { sangat cepat setiap kali berhadapan dengan } \\
\text { kucing. }\end{array}$ \\
\hline 3 & $\mathrm{~S}$ & $\sqrt{ }$ & $\begin{array}{l}\text { Merasa cemas saat melihat kucing, bulu kuduk } \\
\text { berdiri, jijik, dan merasa lemas seketika. } \\
\text { Perasaan cemas terhadap kucing dewasa muncul } \\
\text { dalam jarak } 1 \text { meter. Perasaan cemas terhadap } \\
\text { anak kucing terasa dalam jarak } 3 \text { meter. Apabila } \\
\text { menemukan kucing, S berteriak untuk meminta } \\
\text { bantuan orang lain mengusirnya. }\end{array}$ \\
\hline
\end{tabular}

\section{Pelaksanaan intervensi}

Intervensi hanya dilakukan kepada UK dan CF, karena $\mathrm{S}$ sudah mengundurkan diri dari penelitian. Dalam intervensi, UK lebih konsisten untuk hadir dalam sesi-sesi pertemuan. Berbeda dengan UK, CF seringkali membatalkan sesi. sesi pertama dilakukan dengan mengukur kecemasan partisipan terhadap kucing. Pengukuran detak jantung dan tingkat fobia dilakukan dengan menghadapkan partisipan pada kucing liar dalam jarak 3.5 meter (jarak yang dianggap aman oleh tiap partisipan). Setelah data yang diperoleh cukup mendalam, art therapy mulai diterapkan untuk mengatasi fobia terhadap kucing.

Pembuatan karya seni akan dimulai pada sesi kedua sampai sesi kelima. Proses evaluasi dilakukan di awal, tengah, dan akhir intervensi. Tujuannya adalah untuk memantau perubahan intensitas fobia dari sebelum dan sesudah intervensi. Dalam setiap sesi, relaksasi yang digunakan di awal dan di akhir adalah progressive muscle relaxation, sehingga memerlukan waktu sekitar 20 menit untuk setiap kali relaksasi. Tujuan dilakukannya relaksasi adalah membuat kondisi perasaan klien tetap stabil, sehingga lebih mudah mengatasi kecemasan. Dengan demikian, intervensi dapat dijalankan dengan maksimal. Durasi yang diperlukan untuk intervensi disesuaikan dengan kecepatan klien dalam menghasilkan karya seni dalam setiap sesinya. Berikut ini adalah prosedur intervensi yang secara umum dilakukan pada klien, 


\section{Tabel 2. Prosedur Intervensi}

\begin{tabular}{|c|c|c|c|}
\hline Sesi & $\begin{array}{c}\text { Tahap focusing oriented art } \\
\text { therapy }\end{array}$ & Kegiatan & Tujuan \\
\hline 1 & Tahap 1 (establishing safety) & $\begin{array}{l}\text { Klien diajarkan progressive } \\
\text { muscle relaxation. } \\
\text { Selanjutnya, klien dihadapkan } \\
\text { dengan kucing dan } \\
\text { pengukuran intensitas fobia } \\
\text { dilakukan sebagai evaluasi. Di } \\
\text { akhir sesi, relaksasi kembali } \\
\text { dilakukan. }\end{array}$ & $\begin{array}{l}\text { Mengukur intensitas } \\
\text { fobia klien dan mulai } \\
\text { membina hubungan } \\
\text { terapeutik }\end{array}$ \\
\hline 2 & $\begin{array}{l}\text { Tahap } 1 \text { (establishing safety), } \\
\text { tahap } 2 \text { (empathic } \\
\text { understanding), dan tahap } 3 \\
\text { (integrating art therapy into } \\
\text { focusing) }\end{array}$ & $\begin{array}{l}\text { Klien diminta melakukan } \\
\text { relaksasi terlebih dahulu. } \\
\text { Setelah itu, klien diajak } \\
\text { melukis kucing secara utuh } \\
\text { menggunakan pensil warna. } \\
\text { Seusai melukis, klien diminta } \\
\text { menyentuh bagian-bagian } \\
\text { tubuh kucing yang telah } \\
\text { dilukisnya. Setelah sesi, klien } \\
\text { diminta melakukan relaksasi. }\end{array}$ & $\begin{array}{l}\text { Mengajak klien untuk } \\
\text { mengeksplorasi hal-hal } \\
\text { yang dialami saat } \\
\text { melihat kucing melalui } \\
\text { media seni }\end{array}$ \\
\hline 3 & $\begin{array}{c}\text { Tahap } 2 \text { (empathic } \\
\text { understanding) dan tahap } 3 \\
\text { (integrating art therapy into } \\
\text { focusing) }\end{array}$ & $\begin{array}{l}\text { Klien diminta melakukan } \\
\text { relaksasi terlebih dahulu. } \\
\text { Selanjutnya, klien akan } \\
\text { dihadapkan dengan kucing. } \\
\text { Pegukuran dilakukan seperti } \\
\text { dalam sesi pertama. Relaksasi } \\
\text { dilakukan kembali di akhir } \\
\text { sesi. }\end{array}$ & $\begin{array}{l}\text { Mengetahui penurunan } \\
\text { intensitas fobia dan } \\
\text { perubahan sensasi yang } \\
\text { dirasakan klien. }\end{array}$ \\
\hline 4 & $\begin{array}{c}\text { Tahap } 4 \text { (the felt shift: art and } \\
\text { body) }\end{array}$ & $\begin{array}{l}\text { Relaksasi dilakukan sebelum } \\
\text { sesi. Dalam sesi ini, klien } \\
\text { diminta membuat boneka } \\
\text { kucing (terbuat dari kain } \\
\text { rasfur). Setelah itu, klien } \\
\text { diminta menyentuh seluruh } \\
\text { bagian boneka dan } \\
\text { menceritakan kesannya. } \\
\text { Relaksasi kembali dilakukan } \\
\text { di akhir sesi. }\end{array}$ & $\begin{array}{l}\text { Mengajak klien untuk } \\
\text { mengeksplorasi hal-hal } \\
\text { yang dialami saat } \\
\text { melihat kucing melalui } \\
\text { media seni yang lebih } \\
\text { mirip dengan kucing } \\
\text { sebenarnya. }\end{array}$ \\
\hline 5 & $\begin{array}{c}\text { Tahap } 2 \text { (empathic } \\
\text { understanding), tahap } 3 \\
\text { (integrating art therapy into } \\
\text { focusing), dan tahap } 5 \\
\text { (integrating focusing into art } \\
\text { therapy) }\end{array}$ & $\begin{array}{l}\text { Klien diminta melakukan } \\
\text { relaksasi terlebih dahulu. } \\
\text { Selanjutnya, klien akan } \\
\text { dihadapkan dengan kucing. } \\
\text { Pegukuran dilakukan seperti } \\
\text { dalam sesi ketiga. Relaksasi } \\
\text { dilakukan kembali di akhir } \\
\text { sesi. }\end{array}$ & $\begin{array}{l}\text { Melihat seberapa } \\
\text { mampu klien } \\
\text { mengendalikan dirinya } \\
\text { saat kembali berhadapan } \\
\text { dengan kucing. }\end{array}$ \\
\hline
\end{tabular}




\section{Hasil Intervensi}

Setelah intervensi dilakukan, kecemasan UK mengalami penurunan yang lebih signifikan daripada $\mathrm{CF}$. Hal ini ditandai dengan jumlah rata-rata detak jantung yang lebih rendah dan klasifikasi mild untuk intensitas kecemasan. Selama menjalani sesi, UK juga lebih serius dalam mengerjakan tugas. Ia sempat melakukan relaksasi, serta serius dalam melukis maupun menjahit selama sesi. Dalam sesi kedua, ia sempat tersentak saat melukis bagian wajah kucing, sehingga arsirannya lebih tebal. Dalam sesi kelima, UK mengaku cemas saat memegang bagian wajah boneka kucing.

Berbeda dengan UK, CF tidak selalu menuruti instruksi penulis dalam melukis dan terburu-buru dalam mengerjakannya. Arsiran pada area wajah kucing yang dilukis CF tampak lebih tebal daripada bagian lain. Dalam sesi keempat, CF mengaku tidak cemas selama sesi menjahit, padahal ia sempat tersentak saat melihat kain rasfur. Selama menjahit, CF tergesa-gesa dan tidak teliti, sehingga hasil jahitannya tidak rapi. Penempelan mata dan hidung boneka pun tidak simetris. Secara keseluruhan, kondisi fobia CF menurun hingga kategori moderate.

Tabel 3. Hasil Intervensi UK (Partisipan Pertama)

\begin{tabular}{lccc}
\hline & \multicolumn{3}{c}{ Pengukuran } \\
\cline { 2 - 4 } & Detak Jantung (per menit) & SUDS & $\begin{array}{c}\text { Severity } \\
\text { Measure for Specific Phobia - } \\
\text { Adult }\end{array}$ \\
\hline Sesi 1 & 86 & 70 & 3.8 (severe) \\
Sesi 2 & & 85 & 2.7 (moderate) \\
Sesi 3 & 84 & 70 & \\
Sesi 4 & & 30 & 1.7 (mild) \\
Sesi 5 & & 60 & \\
Sesi 6 & 80 & 50 & \\
\hline
\end{tabular}

Tabel 4. Hasil Intervensi CF (Partisipan Kedua)

\begin{tabular}{lccc}
\hline & & Pengukuran & \\
\cline { 2 - 4 } & Detak Jantung (per menit) & SUDS & $\begin{array}{c}\text { Severity Measure for Specific } \\
\text { Phobia - Adult }\end{array}$ \\
\hline Sesi 1 & 87 & 60 & 3.7 (severe) \\
Sesi 2 & & 10 & 3.2 (moderate) \\
Sesi 3 & 86 & 70 & \\
Sesi 4 & & 10 & 2.8 (moderate) \\
Sesi 5 & 82 & 50 & \\
\hline
\end{tabular}




\section{KESIMPULAN DAN SARAN}

Berdasarkan hasil evaluasi, ditemukan adanya penurunan intensitas fobia terhadap kucing pada kedua partisipan. Baik UK, maupun CF, keduanya sudah lebih tenang dalam menghadapi kucing daripada sebelum intervensi. Terkait hal ini, kedua partisipan tidak terlalu menghindari kucing seperti sebelumnya dan sudah cukup mampu mengusir kucing. Berdasarkan hasil evaluasi, kondisi fobia UK dan CF terhadap kucing sudah mengalami penurunan. Jika dilihat dari hasil observasi, UK menunjukkan kemajuan yang lebih baik dalam proses intervensi. Hal ini terjadi karena ia sempat berlatih relaksasi dan berinisiatif untuk mengatakan "tenang" dalam pemikirannya selama berhadapan dengan kucing. Sementara itu, CF tidak pernah berlatih relaksasi maupun mempraktikkannya saat berhadapan dengan kucing.

\section{Diskusi}

Berdasarkan penelitian yang dilakukan Uttley et al. (2015), group art therapy terbukti dapat menurunkan intensitas gangguan-gangguan psikologis, temasuk fobia. Hasil uji beda statistik berdasarkan Severity Measure for Specific Phobia dalam penelitian ini tidak menunjukkan penurunan intensitas fobia yang signifikan pada kedua partisipan $(\mathrm{t}=2.500, \mathrm{p}=.228>.05)$. Hal ini disebabkan oleh jumlah partisipan yang sedikit, sehingga tidak dapat dipastikan secara statistik apakah art therapy yang diterapkan benar-benar dapat menurunkan intensitas fobia terhadap kucing. Selain itu, hasil yang tidak signifikan juga terjadi karena salah satu partisipan kurang kooperatif selama intervensi, dan kurangnya waktu yang dibutuhkan untuk intervensi.

Dalam proses intervensi UK, penurunan intensitas fobia kucing lebih jelas daripada kasus CF. Hal ini terjadi karena UK sempat melakukan relaksasi di rumah sebagai tugas, walaupun hanya di sesi-sesi awal. Sejak akhir sesi ketiga, UK menerapkan relaksasi pada bagian otot yang paling tegang saja, yaitu bagian belakang leher, setiap kali berhadapan dengan kucing. UK juga selalu mengatakan "tenang" dalam pemikirannya selama berhadapan dengan kucing. Ia pun bersikap kooperatif selama membuat karya seni dan mengerjakannya dengan serius. Setelah dievaluasi, penerapan art therapy pada UK menurunkan intensitas fobia yang sebelumnya berada dalam kategori severe menjadi mild.

Berbeda dengan UK, CF tidak pernah melakukan relaksasi selama intervensi dilakukan. Setiap kali berhadapan dengan kucing, relaksasi juga tidak dilakukan. Selain itu, CF juga seringkali membatalkan sesi pertemuan untuk intervensi. Selain itu, CF juga cenderung tidak mengakui perasaan cemasnya dalam sesi melukis dan menjahit. Dengan demikian nilai SUDS yang ia berikan selama dihadapkan dengan kucing dan selama intervensi sangat berbeda.

\section{Saran kepada peneliti selanjutnya}

Apabila penelitian serupa akan dilakukan, variasi stimulus yang terkait dengan kucing dapat ditambahkan selama intervensi, misalnya melukis atau membuat boneka berbagai jenis kucing Partisipan pun akan terbiasa mengatasi kecemasan terhadap jenis-jenis kucing yang berbeda. Selain itu akan lebih baik jika mengalokasikan lebih banyak waktu untuk intervensi dan melibatkan lebih banyak partisipan. Dengan demikian, hasil evaluasi akan lebih akurat.

\section{Ucapan Terima Kasih}

Penulis berterima kasih kepada partisipan yang terlibat dalam penelitian ini. Penulis juga mengucapkan terima kasih kepada Ibu Sri Tiatri yang sempat memberikan arahan-arahan bermanfaat dalam menyusun proposal penelitian, baik dari aspek penulisan ilmiah, konten materi, maupun metodologi penelitian. 


\section{REFERENSI}

American Psychiatric Association. (2000). Diagnostic and statistical manual of mental disorders (4th ed., text revision). Washington, DC: Author.

Anastasia, M. (September, 2016). Inilah 10 tempat favorit di Jakarta terfavorit pengunjung. Diunduh dari http://www.initempatwisata.com/wisata-indonesia/jakarta/inilah-10-tempatnongkrong-di-jakarta-terfavorit-pengunjung/4234/

Diana, \& Wirawan, H. E. (2010). Penerapan cognitive behavior therapy untuk mengatasi fobia kecoa pada remaja. Arkhe, 15(1), h. 11-17.

Edwards, D. (2004). Art therapy. London, UK: Sage.

Harrison, T. R., \& Morgan, S. E. (2005). Hanging out among teenager. In C. Morrill, D. A. Snow, \& C. H. White (Eds.), Together alone. (pp. 94). London, UK: University of California Press.

Hogan, S., \& Coulter, A. M. (2014). The introductory guide to art therapy: Experiential teaching and learning for students and practitioners. New York, NY: Routledge.

Kraft, D., \& Kraft, T. (2010). Use of in vivo and in vitro desensitization in the treatment of mouse phobia: Review and case study. Contemporary Hypnosis, 27(3), 184-194.

Lebeau, R. T., Glenn, D. E., Hanover, L. E., Beesdo-Baum, K., Wittchen, H. U., \& Craske, M. G. (2012). A dimensional approach to measuring anxiety for DSM-5. International Journal of Methods in Psychiatric Research. 21(4), 258-272. doi: 10.1002/mpr.1369

McGlynn, F. D., \& Cornell, C. E. (1985). Simple phobia. In M. Hersen, \& A. S. Bellack (Eds.), Handbook of clinical behavior therapy wth adults (pp. 33). New York, NY: Plenum Press.

Rappaport, L. (2009). Focusing-oriented art therapy. Philadelphia, PA: Jessica Kingsley Publishers.

Rimawan, R.. (Mei, 2014). 'Ledakan' populasi kucing liar di Jakarta mengkhawatirkan. Tribun Manado. Diunduh dari: http://manado.tribunnews.com/2014/ 05/05/ledakan-populasi-kucing-liar-di-jakarta-mengkhawatirkan

Sinaga, A. P. (Oktober, 2014). Perlu lebih banyak komunitas penampung hewan liar. . Diunduh dari http://www.tubasmedia.com/perlu-lebih-banyak-komunitas-penampung-hewan-liar/

Sue, D., Sue, D. W., dan Sue, S. (2010). Understanding abnormal behavior (9th ed.). Belmont, CA: Wadsworth Cengage Learning.

Uttley, L., Stevenson, M., Scope, A., Rawdlin, A., \& Sutton, A. (2015). Clinical and cost effectiveness of group art therapy for people with non-psychotic mental health disorders: A systematic review and cost effectiveness analysis. BMC Psychiatry, 15(151), 1-13. doi: 10.1186/s12888-015-0528-4

Wadeson, H. (1980). Art psychotherapy. Canada, CA: John Wiley \& Sons.

Wima, P. (September, 2015). 8 derita ini cuma orang ga suka kucing aja yang memahami!. Diunduh dari http://www.hipwee.com/hiburan/8-derita-ini-cuma-orang-yang-gak-sukakucing-aja-yang-memahami/ 